Methods In this clinical investigation, we retrospectively evaluated hospital records of patients who were hospitalised in our Infectious Diseases Service from January 1990 through September 2000 to investigate the cause of prolonged fever. One hundred forty-five patients (63 female, 82 male, mean age: 38.5 , min-max: 16-80) meeting the classical criteria of FUO were included in the present study.

Results Infections, rheumatic diseases and malign disorders were found in $93(64.1 \%), 24(16.6 \%)$ and 8 patients (5.5\%), respectively. Infectious causes are the most common cause in all age groups, and rheumatic disease are the second. Malign diseases were diagnosed in $2.7 \%$ of patients under age 50 , and percentage of these disorders increased to $15.6 \%$ among patients over 50. Miscellaneous conditions were found in 2 patients $(1.4 \%)$, and despite detailed evaluation 18 patients (12.4\%) remained undiagnosed. List of rheumatic diseases diagnosed as causes of FUO in the present study are given in Table 1.

\begin{tabular}{lll}
$\begin{array}{l}\text { Abstract THU0231 Table 1 } \\
\text { as causes of FUO }\end{array}$ & List of rheumatic diseases diagnosed \\
\hline FMF & Frequency & Percent \\
Unclassified collagen tissue disease & 2 & 8.3 \\
Sarcoidosis & 4 & 16.6 \\
Seronegative arthritis & 2 & 8.3 \\
SLE & 2 & 8.3 \\
Temporal arteritis & 3 & 12.5 \\
PAN-like vasculitis & 2 & 8.3 \\
Others (Behçet's D, PM, Still's, RA, WG) & 4 & 16.6 \\
\hline
\end{tabular}

Conclusion In conclusion, despite widespread use of antibiotics and increasingly useful diagnostic technologies, infectious disease still remain the leading cause of FUO among our group of patients, and collagen vascular diseases together with granulomatous disorders are the second most common group. The percentage of tumours was higher in our elderly patients than in the younger ones but still clearly lower than other causes of FUO in adults. Infectious Diseases Department of Hacettepe University is one of the reference centres in Turkey, and many undiagnosed cases are being referred to our hospital. Therefore we believe that, although we performed the present study only from our hospital reports, the results may reflect the general population of central Anatolia.

\section{THU0232 FAS AND APOPTOSIS IN PATIENTS WITH FAMILIAL MEDITERRANEAN FEVER AND AMYLOIDOSIS}

${ }^{1} S$ Kiraz, ${ }^{1}$ I Ertenli, ${ }^{1} \mathrm{M}$ Çalgüneri, ${ }^{1} \mathrm{MA}$ Oztürk, ${ }^{2} \mathrm{E}$ Atalar, ${ }^{1} \mathrm{~S}$ Apras, ${ }^{3} \mathrm{C}$ Haznedaroglu, ${ }^{3} S$ Kirazl. ${ }^{1}$ Rheumatology; ${ }^{2}$ Cardiology; ${ }^{3}$ Hematology, Hacettepe University School of Medicine, Ankara, Turkey

\subsection{6/annrheumdis-2001.764}

Background Amyloidosis is the drastic complication of familial Mediterranean Fever (FMF). Amyloidosis may be characterised by a tendency for keratinocytes to undergo filamentous degeneration and apoptosis. However, a possible association of FMF and apoptosis has not been previously evaluated. Binding of Fas ligand (FasL) to the Fas antigen trigger the cytoplasmic apoptotic signal. Induced cell death can be inhibited by soluble Fas protein
(sFas) which binds to and functions as competitive antagonist of FasL.

Objectives The aim of this study was to investigate sFas in patients with FMF complicated with amyloidosis compared to FMF patients without amyloidosis and controls.

Methods Ten FMF patients with amyloidosis (mean age: 41.8, min-max: 33-51), 12 patients with FMF without amyloidosis (mean age: 24.8, min-max: 17-38) and 16 controls (mean age: 48.7, min-max: 38-63) were enrolled in the study. All FMF patients were in attack-free period during blood sampling. sFas levels were measured using a commercially available ELISA kit (Quantikine sFas Immunoassay).

Results

Conclusion Decreased serum sFas levels may lead to unbalanced binding of FasL to its receptor, inducing apoptosis. In vitro experiments demonstrated that long-term enhancement of Fas expression in Fas-normal mice resulted in an increased acutephase response and renal amyloidosis in aged transgenic mice. Increased Fas expression in T cells of aged CD2-Fas transgenic CD-1 mice resulted in an increased immune response and T cell apoptosis. Therefore, enhanced Fas-mediated apoptosis can be associated with amyloidosis in FMF patients, and this association may be related to the dysregulated immune system activation. On the other hand, elevated levels of sFas protein in patients with FMF may also be related to the imbalanced inflammatory activity. Induced cell death of autoreactive T cells could be inhibited by sFas. sFas levels were shown to be elevated in patients with active SLE. However this observation could not be confirmed by some other authors. Since the changes in autoimmune inflammatory disorders are dynamic and complex, it is difficult to establish a relationship between $s F a s$ and their pathogenesis. It also remains to be detected which cells release the elevated amounts of sFas. Future studies are needed to elucidate exact state of sFas protein in the etiopathogenesis of FMF.

\section{THU0233 HYPERMOBILITY SYNDROME - A DISEASE OR NOT A DISEASE}

Y Gazit, AM Nahir. B. Shine Department of Rheumatology, Rambam Medical Center, Haifa, Israel

10.1136/annrheumdis-2001.765

Background Although benign joint hypermobility syndrome (BJHS) is very common in the general population, the diagnosis is frequently missed. The reasons may be that BJHS is not a life threatening condition and most BJHS patients conduct normal life. Unfortunatly, most BJHS patients are frustrated, wandering from one physician to the other.

Objectives To evaluate whether people with BJHS regard themselves as healthy or ill.

Methods Forty people were diagnosed as having BJHS in a rheumatology clinic and were compared to 26 healthy controls. A skilled rheumatologist reviewed and examined all of them and fulfilled a questionnaire about their articular and non articular complaints as well as their well being. The questionnairs were statistically analysed.

Results All BJHS patients were working and conducing active life. In average, BJHS patients suffered from joint pain in 8.53 joints in the last 3 months, opposed to 0.77 joints in the control group. $58 \%$ of the BJHS patients, but non of the controls had considered themself ill. On a direct question, all those who 
regard themselves as ill pointed their joints as the reason for it, although $30 \%$ of them had extra articular manifestations.

Conclusion Most of the people suffering from BJHS consider themselves ill. BJHS should be looked at as a disease by the Physician.

\section{THU0234 FAMILIAL MEDITERRANEAN FEVER: ANALYSIS OF 45 TUNISIAN PATIENTS}

SS Turki, CH Ben Taarit, R Goucha, E Abderrahim, F Ben Moussa, H Ben Maiz. Department of Nephrology and Internal Medicine, Charles Nicolle Hospital, Tunis, Tunisia

\subsection{6/annrheumdis-2001.766}

Background Familial mediterranean fever (FMF) is an inherited multisystem disease of unknown aetiology, characterised by recurrent, painful, self-limited episodises.

Objectives The objectives of this study is to describe the clinical profile, course and complications of 45 cases of FMF observed over a period of 25 years.

Methods Retrospective review of 45 cases with FMF.

Results Forty patients (88\%) started their illness below the age of 10 years. Peritonitis occured in $84,4 \%$, arthritis in $35,5 \%$, pleuretis in $17,7 \%$ and erysipelas-like lesions in $31,1 \% .21$ patients developed renal amyloïdosis and 17 patients were subjected to unnecessary operative surgery.

The arthritis was monoarticular in $85 \%$ and polyarticular in $15 \%$ and was seronegative in all cases (Rheumatoid factor and antinuclear antibodies). The synovial attack showed a wide variation in the clinical presentation, course and duration of arthritis causing diagnostic difficulties.

Renal amyloïdosis occured in 21 patients after a mean duration of FMF 10,5 years ( 2 to 28 years). One patient had hematuria, kidney biopsy showed mesangial IgA glomerulonephritis. Among 32 patients treated with colchicine, $80 \%$ achieved a therapeutic response.

Conclusion FMF is an inherited disease; colchicine remains the only efficient treatment to prevent both acute manifestations and amyloïdosis.

\section{THU0235 TREATMENT OF REFRACTORY POSTERIOR UVEITIS WITH ANTI-TNF-ALFA (INFLIXIMAB)}

A Banares, E Pato, L Abasolo, P Macarron, C Hernandez, JA Jover, B Fernandez. Rheumatology, Hospital Clinico San Carlos, Madrid, Spain

\subsection{6/annrheumdis-2001.767}

Background There is a group of patients with non-infectious posterior uveitis (PU) who are refractory to corticosteroid or immunosuppressive (IS) regimens. The important role played by TNF-a in experimental uveitis models, and the efficacy shown by the various anti-TNF-a agents in autoimmune diseases have been reported.

Objectives To demonstrate the usefulness of infliximab in the treatment of non-infectious PU.

Methods Open, non-controlled trial, including 7 patients with corticosteroid-refractory PU who were receiving one or more of the following IS agents for a minimum of 2 years: CsA, AZA, MTX. Treatment was administered on a compassionate use basis, after EC approval at our institution and patient informed consent. All IS agents except MTX were discontinued one month prior to the start of treatment. Prednisone dose was adjusted to
$0.5 \mathrm{mg} / \mathrm{kg} / \mathrm{day}$ and decreased by $5 \mathrm{mg} / \mathrm{day}$ every week in the absence of posterior pole inflammation. Three doses of $5 \mathrm{mg} / \mathrm{kg}$ infliximab were administered IV at weeks 0,2 , and 6 . Visits including a full ophthalmological assessment took place at weeks $1,3,4,5,7,8$, and 12; fluorescein angiographies (FAG) and retinograms were performed at baseline and week 16 .

Results No adverse effects, and no ocular or systemic exacerbations were observed. Final prednisone dose was $=$ or $<7.5 \mathrm{mg}$ for six patients, and $15 \mathrm{mg}$ for patient 2. Vitreous haze improved in all patients except patient 7. Measurable improvement of visual acuity was documented in patients $2,3,4,5$, and 6. FAGs and retinograms confirmed vitreous clearance in all patients, showing improvement of active retinal bleeding in patient 4 and disappearance of a macular oedema (which had been present for years) in patient 5 . Only patient 7 , with chronic multifocal choroiditis, had no improvement.

\begin{tabular}{|c|c|c|c|c|c|c|}
\hline & Diagnosis & $\begin{array}{l}\text { Posterior } \\
\text { pole }\end{array}$ & $\begin{array}{l}\text { Visual } \\
\text { acuity* } \\
\text { Snellen } \\
\text { scale } \\
\text { Baseline }\end{array}$ & $\begin{array}{l}\text { Visual } \\
\text { acuity* } \\
\text { Snellen } \\
\text { scale } \\
\text { Week12 }\end{array}$ & $\begin{array}{l}\text { Vitreous } \\
\text { haze } \\
\text { Nussenblatt } \\
\text { scale } \\
\text { Baseline }\end{array}$ & $\begin{array}{l}\text { Vitreous } \\
\text { haze } \\
\text { Nussenblatt } \\
\text { scale } \\
\text { Week12 }\end{array}$ \\
\hline $\begin{array}{l}\text { Patient } \\
1\end{array}$ & $\begin{array}{l}\text { Behcet } \\
\text { dis. }\end{array}$ & Vasculitis & $20 / 25$ & $20 / 25$ & 0 & 0 \\
\hline $\begin{array}{l}\text { Patient } \\
2\end{array}$ & $\begin{array}{l}\text { Behcet } \\
\text { dis. }\end{array}$ & Vasculitis & $20 / 32$ & $20 / 28$ & \pm & 0 \\
\hline $\begin{array}{l}\text { Patient } \\
3\end{array}$ & $\begin{array}{l}\text { Behcet } \\
\text { dis. }\end{array}$ & Vasculitis & $20 / 32$ & $20 / 28$ & \pm & 0 \\
\hline $\begin{array}{l}\text { Patient } \\
4\end{array}$ & $\begin{array}{l}\text { Behcet } \\
\text { dis. }\end{array}$ & Vasculitis & $20 / 125$ & $20 / 100$ & $2+$ & \pm \\
\hline $\begin{array}{l}\text { Patient } \\
5\end{array}$ & $\begin{array}{l}\text { Behcet } \\
\text { dis. }\end{array}$ & Vasculitis & $20 / 200$ & $20 / 100$ & $2+$ & \pm \\
\hline $\begin{array}{l}\text { Patient } \\
6\end{array}$ & Sarcoidosis & Vasculitis & $20 / 40$ & $20 / 28$ & $2+$ & \pm \\
\hline $\begin{array}{l}\text { Patient } \\
7\end{array}$ & $\begin{array}{l}\text { Multifocal } \\
\text { choroiditis }\end{array}$ & Chorioretinitis & $\mathrm{CF}$ & CF & $1+$ & $1+$ \\
\hline
\end{tabular}

Conclusion In this preliminary open trial, infliximab treatment appears to be a useful option in the short term for the management of refractory PU patients with retinal vasculitis.

\section{THU0236 UNDIFFERENTIATED CONNECTIVE TISSUE DISEASE: OUTCOME OF 40 PATIENTS}

M Romero, MA Aguirre, A Cisnal, P Font, MJ Cuadrado, FG Martinez, J Gonzalez, A Escudero, V Perez, C Castro, MC Muñoz-Villanueva, E Collantes. Rheumatology Service, Hospital Universitario Reina Sofia, Cordoba, Spain

10.1136/annrheumdis-2001.768

Background There are a substantial number of patients with symptoms strongly suggestive of a connective tissue disease (CTD) that does not adequately fulfil enough classification criteria to be labelled as such. The outcome of these patients is difficult to predict. They are classified as undifferentiated connective tissue disease (UCTD).

Objectives To prospectively analyse the outcome of a cohort of patients with UCTD. 